\title{
FISCHERELLIN, A NEW ALLELOCHEMICAL FROM THE FRESHWATER CYANOBACTERIUM FISCHERELLA MUSCICOLA ${ }^{1}$
}

\author{
Elisabeth M. Gross ${ }^{2}$
}

Max-Planck-Institut für Limnologie, Abteilung Ökophysiologie, D-2320 Plön, Federal Republic of Germany

\section{Peter Wolk}

MSU-DOE Plant Research Laboratory and Center for Microbial Ecology, Michigan State University, East Lansing, Michigan 48824-1312

and

\section{Friedrich Jüttner ${ }^{2,3}$}

Max-Planck-Institut für Limnologie, Abteilung Ökophysiologie, D-2320 Plön, Federal Republic of Germany

\section{ABSTRACT}

The benthic cyanobacterium Fischerella muscicola (Thur.) Gom. UTEX 1829 produces a secondary metabolite, fischerellin, that strongly inhibits other cyanobacteria

\footnotetext{
${ }^{1}$ Received 22 April 1991. Accepted 1 August 1991.

${ }^{2}$ Addresses for reprint requests.

s Present address: Institut für Pflanzenbiologie/Limnologie, Universität Zürich, Seestr. 187, CH-8802 Kilchberg, Switzerland.
}

and to a lesser extent members of the Chlorophyceae. Eubacteria are not affected. The major active compound is lipophilic and exhibits a molecular ion at $\mathrm{m} / \mathrm{z} 408$. It is heat-and acid-stable but decomposes in $1 \mathrm{M}$ sodium hydroxide $\left(80^{\circ} \mathrm{C}, 1 \mathrm{~h}\right)$. Fischerellin inhibits the photosynthetic but not the respiratory electron transport of cyanobacteria and chlorophytes. Its site of action is located in PS II. Two other species of Fischerella also produce fischerellin, indicating that the synthesis of such allelochemicals might be characteristic of the genus.

Konstanzer Online-Publikations-System (KOPS)

URL: http://www.ub.uni-konstanz.de/kops/volltexte/2008/4848/

URN: http://nbn-resolving.de/urn:nbn:de:bsz:352-opus-48488 
Key index words: algicide; allelochemical; allelopathy; cyanobacteria; Fischerella muscicola; photosystem II inhibitor; secondary metabolite

In late summer, cyanobacterial blooms of a single species often dominate in eutrophic lakes, and cyanobacterial mats consisting of only one species are frequently reported in benthic habitats (Cohen and Rosenberg 1989). Several factors lead to the mass development of cyanobacteria (Paerl 1988), including (in different species) high growth rates, tolerance to desiccation, and the production of allelochemicals.

Since Molisch (1937) coined the term allelopathy, several investigations have been made upon the role of allelochemicals and allelopathic interactions of cyanobacteria and algae (Pratt 1942, Lefèvre 1964, Keating 1977, 1978, Patterson et al. 1979, Rice 1984). In none of these were the substance or substances responsible for the inhibitory or stimulatory activity isolated and characterized. In recent years, algicidal compounds from benthic and edaphic cyanobacteria have been elucidated. Cyanobacterin, a secondary metabolite of Scytonema hofmanni UTEX 2349 that inhibits PS II has been extensively studied (Mason et al. 1982, Pignatello et al. 1983, Gleason and Paulson 1984, Gleason and Baxa 1986, Gleason and Case 1986, Gleason 1990). Hapalindole A and related algicidal compounds from Hapalosiphon fontinalis (Ag.) Bornet, strain V-3-1 were elucidated by Moore and coworkers (1984, 1987a, b, 1989). The hapalindolinones of Fischerella ATCC 53558 inhibit arginine vasopressin binding (Schwartz et al. 1987). Pharmacological screening programs may, though not primarily so intended, identify secondary metabolites that play a role in chemical interactions in ecosystems.

Flores and Wolk (1986) screened 65 filamentous, nitrogen-fixing cyanobacteria for the production of bacteriocins and other antibiotics that kill related strains. Of the seven strains that were found to produce effective antibiotics only Fischerella muscicola UTEX 1829 was shown to synthesize a substance (or substances) that kills all indicator strains tested. The substance was protease insensitive and dialyzable. We have now isolated and partially characterized the active compound, which we call fischerellin. Additional indicator strains were tested, and the mode of action of fischerellin was determined.

\section{MATERIALS AND METHODS}

Fischerella muscicola (Thur.) Gom. UTEX 1829 (Flores and Wolk 1986) and Fischerella ambigua (Näg.) Gom. UTEX 1903 were obtained from the Culture Collection of Algae at the University of Texas at Austin, Department of Botany, Austin, Texas. Fischerella tisserantii Frémy Kom. 1964/47 was obtained from Dr. Kováčik, Czechoslovak Academy of Sciences, Institute of Botany, Treboñ, Czechoslovakia. Other cyanobacteria, algae, and eubacteria were obtained from sources shown in Table 1. All cultures except $F$. tisserantii Frémy and Senedesmus obliquus (Turp.) Kütz were axenic.
Cyanobacteria were maintained on cyanobacterial medium (Jüttner et al. 1983), and members of the Chlorophyceae on chlorophycean medium (Kuhl 1962). Both were grown at $25^{\circ} \mathrm{C}$ and $20 \mu \mathrm{E} \cdot \mathrm{s}^{-1} \cdot \mathrm{m}^{-2}$. Members of the eubacteria were grown either in NB-medium ( $8 \mathrm{~g}$ nutrient broth [Difco] in $1 \mathrm{~L}$ of distilled water) or in CPS-medium (Collins 1963). Indicator strains were grown at $28^{\circ} \mathrm{C}$ in $300-\mathrm{mL}$ Erlenmeyer flasks in a controlled environment incubator shaker $\left(100 \mathrm{~mL}\right.$ of suspension, $120 \mathrm{rpm}, 50 \mu \mathrm{E} \cdot \mathrm{s}^{-1}$. $\left.\mathrm{m}^{-2}\right)$. Fischerella spp. was pregrown in $300-\mathrm{mL}$ tubes $\left(60 \mu \mathrm{E} \cdot \mathrm{s}^{-1}\right.$. $\mathrm{m}^{-2}$ ) and aerated with $0.3 \mathrm{~L} \cdot \mathrm{min}^{-1}$ compressed air enriched to $0.2 \% \mathrm{CO}_{2}$ (Jüttner 1982) and mass cultured in 5-L tubes (100 $\mu \mathrm{E} \cdot \mathrm{s}^{-1} \cdot \mathrm{m}^{-2}, 0.5 \mathrm{~L} \cdot \mathrm{min}^{-1}$ compressed air, enriched to $\left.0.2 \% \mathrm{CO}_{2}\right)$. both at $28^{\circ} \mathrm{C}$.

Fischerella was harvested by filtration through a $100-\mu \mathrm{m}$ net and freeze-dried. Average yields were $4 \mathrm{~g}$ fresh weight $(0.4 \mathrm{~g}$ dry weight) per liter of culture suspension. One gram of lyophilized cells was extracted three times with $50 \mathrm{~mL}$ of methanol for 15 $\mathrm{min}$ in an ultrasonic bath. An equal amount of $10 \mathrm{mM}$ citric acidcitrate buffer $(10 \mathrm{mM} \mathrm{HCl}$ adjusted with $10 \mathrm{mM}$ sodium citrate solution $[2.1 \mathrm{~g}$ of citric acid hydrate dissolved in $20 \mathrm{~mL}$ of $1 \mathrm{M}$ sodium hydroxide and made up to $1 \mathrm{~L}$ with distilled water] to $\mathrm{pH} 2.2$ ) was added to the combined extracts. After filtration, the extract was partitioned twice with half the amount of tert-butylmethylether: the ether phases were combined, dried over anhydrous sodium sulfate, and evaporated to dryness. The residue was dissolved in $1.5 \mathrm{~mL}$ of methanol and subjected to reversed phase HPLC separation on a $25 \times 0.46-\mathrm{cm}$ LC18-column (No. 5-8298, Supelco, Bad Homburg, F.R.G.). Aliquots of 50-100 $\mu \mathrm{L}$ were separated by isocratic chromatography with methanol/water $(99: 1 ; \mathrm{v} / \mathrm{v})$ using a flow rate of $1 \mathrm{~mL} \cdot \mathrm{min}^{-1}$. Absorptions at 267 and $415 \mathrm{~nm}$ were monitored to detect the active substances and contaminating pigments, respectively. One-milliliter fractions of the eluate were bioassayed by the agar diffusion test (see below). Further purification of the active compound was achieved by separation on a $10 \times 0.3-\mathrm{cm}$ LC8-column (Chrompack, Frankfurt/M., F.R.G.) by gradient elution (20-99\% methanol in water $[\mathrm{v} / \mathrm{v}]$ at a flow rate of $\left.1 \mathrm{~mL} \cdot \mathrm{min}^{-1}\right)$.

The amount of fischerellin in the culture medium was determined by passing $250 \mathrm{~mL}$ of medium through a C18-cartridge (500 mg of sorbens, Analytichem International, Frankfurt/M., F.R.G) and subsequently eluting this cartridge first with $5 \mathrm{~mL}$ of methanol and afterward with $5 \mathrm{~mL}$ of tert-butylmethylether. The eluate was evaporated under vacuum, redissolved in methanol, and subjected to the HPLC separation and agar diffusion assay.

Because the amount of purified fischerellin was not sufficient to determine the specific or molar extinction coefficients, fischerellin was quantified by its absorption maximum at $267 \mathrm{~nm}$ in methanol. Quantitative data refer to the absorption of the methanolic solution measured in a $1-\mathrm{cm}$ cuvette.

It was possible to separate and analyze fischerellin by gas chromatography combined with mass spectrometry (5790 A MSD, Hewlett Packard, Böblingen, F.R.G.) using a fused silica capillary column (SIM-DIST-CB, $10 \mathrm{~m}$ length, $0.32 \mathrm{~mm}$ inner diameter, Chrompack, Frankfurt/M., F.R.G.). One microliter of a solution of fischerellin in tert-butylmethylether was injected and separated by the following temperature program: $150-285^{\circ} \mathrm{C}, 10^{\circ} \mathrm{C} \cdot \mathrm{min}^{-1}$, $10 \mathrm{~min}$ isotherm at $285^{\circ} \mathrm{C}$, injection port and interface temperature at $285^{\circ} \mathrm{C}$. Helium was used as the carrier gas (90 kPa head pressure). To detect $\mathrm{H}$-reactive substituents, $2 \mu \mathrm{L}$ of concentrated fischerellin solution in ter/-butylmethylether were evaporated to dryness in a stream of nitrogen and redissolved in $2 \mu \mathrm{L}$ each of $\mathrm{N}, \mathrm{O}$-bis-(trimethylsilyl)-trifluoroacetamide (BSTFA) and N,N-dimethylformamide (DMFA). After $15 \mathrm{~min}$ a GC/MS analysis was performed.

The biomasses of different strains of Fischerella and sterile cell extracts were tested for inhibitory activity by a slight modification of the agar diffusion assay described by Flores and Wolk (1986). Methanolic or ethanolic cell extracts (usually $5 \mu \mathrm{L}$ ) were diluted with an equal amount of sterile water and spotted on plates of 


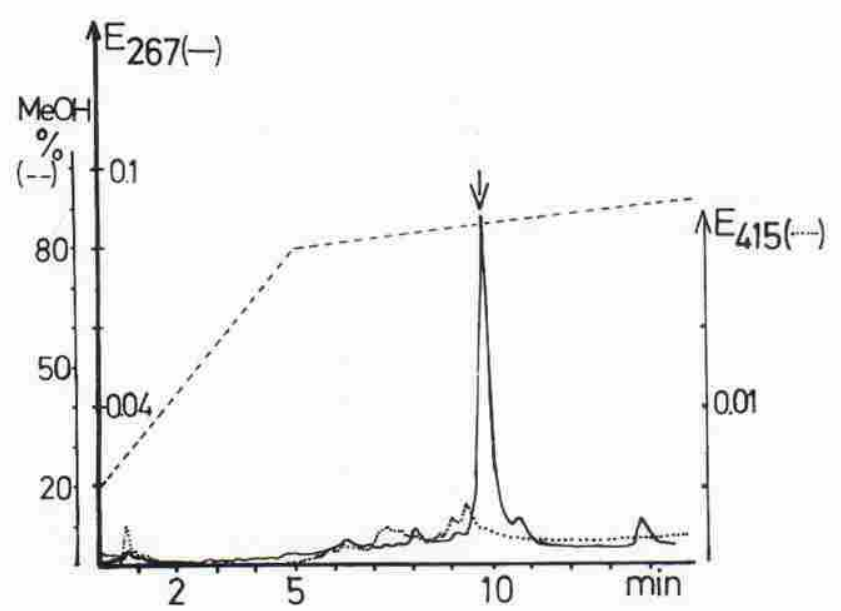

Fig. 1. C8-HPLC separation of purified fischerellin. Gradient elution from 20 to $99 \%$ methanol in water $(v / v)$ at a flow rate of $1 \mathrm{~mL} \cdot \mathrm{min}^{-1}$ and detection at 267 and $415 \mathrm{~nm}$.

medium solidified with $1 \%$ agar. The liquid was dried in a stream of sterile air and the plate was then overlaid with $10 \mathrm{~mL}$ of a suspension of indicator cells in agar $(1 \%)$. Inhibitory activities could be seen by an area of clearing around cell inocula or spots after 3-10 days of incubation in the light. Quantification of the inhibitory effects was estimated by preparing serial dilutions and by the resulting diameter of the clearing zones. Controls were performed with $50 \%$ methanol or ethanol in sterile water.

To determine the effect of fischerellin on the growth of liquid cultures of Synechococcus, different concentrations of fischerellin dissolved in $150 \mu \mathrm{L}$ of ethanol were added to $150 \mathrm{~mL}$ of a growing culture $\left(5 \times 10^{4}\right.$ cells $\left.\cdot \mathrm{mL}^{-1}\right)$ three days after inoculation. Control cultures received an equal amount of ethanol. Optical density was determined at $530 \mathrm{~nm}$ and cell number with the cell analyzer system, Casy 1 (Schärfe System, Reutlingen, F.R.G.). Chlorophyll $a(\operatorname{chl} a)$ was determined spectrophotometrically after extraction with cold methanol as described by Wu and Jüttner (1988). Protein was determined with amido black (Schaffner and Weissmann 1973).

Rates of photosynthetic evolution of $\mathrm{O}_{2}$ by the $\mathrm{P} 9$ derivative of Anabaena variabilis ATCC 29413 and of respiratory uptake of $\mathrm{O}_{2}$ by Nannochloris sp. were measured with a Clark type electrode that was mounted in a $1.2-\mathrm{mL}$ cuvette. The addition of chemicals followed procedures given by Allen and Holmes (1986). Cultures were harvested during the postexponential growth phase by centrifugation, washed, and resuspended in $50 \mathrm{mM}$ sodium phosphate buffer, pH 7.9 (Scherer et al. 1988). The resulting suspension was diluted in this buffer in the cuvette to yield $17 \mu \mathrm{g} \mathrm{chl}$. $\mathrm{mL}^{-1}$. To measure the effect of fischerellin on photosystem II (PS II), the basal rate of electron transport of PS II was determined after addition of 2,6-dichlorophenol-indophenol (167 $\mu \mathrm{M}$ DCPIP) that inhibited PS I and served as an artificial electron acceptor of PS II. Electron transport of PS II was subsequently determined in the presence of fischerellin, atrazine, or ethanol.

In the case of PS I the basal rate was determined in the presence of 3-(3,4-dichlorophenyl)-1,1-dimethylurea (12.5 $\mu \mathrm{M}$ DCMU). Because no artificial electron donor was added, the resulting electron transport was very low. After addition of sodium ascorbate $(4.2 \mathrm{mM}) /$ DCPIP $(167 \mu \mathrm{M})$ as artificial electron donor and $8.3 \mu \mathrm{M} \mathrm{N}, \mathrm{N}$-dimethyl-4-nitrosoaniline (PNDA) as artificial electron acceptor, the electron transport was measured after the addition of fischerellin, atrazine, or ethanol.

\section{RESULTS}

Isolation of fischerellin. Freshly harvested cells of Fischerella or lyophilized cell material were extracted with methanol as described above. To obtain a better separation of fischerellin from chlorophyll $a$ and derivatives of chlorophyll, the acidic extraction procedure was established. The methanolic crude extract was treated with citric acid/citrate buffer to convert chlorophyll into phaeophytin. This procedure resulted in a crude extract that contained only low amounts of chlorophyll derivatives. The methanolic crude extract was further subjected to reversed phase HPLC separation on a C18-column. As indicated by the agar diffusion assay, the fraction of the HPLC separation responsible for most of the activity contained a sharp peak at $7.2 \pm 0.1 \mathrm{~min}$ when the absorption at $267 \mathrm{~nm}$ was recorded. When this fraction was chromatographed on a C8-HPLC column in a solvent gradient (Fig. 1), only one peak appeared that was responsible for all the inhibitory activity and that coeluted with the compound absorbing strongly at $267 \mathrm{~nm}$. Because the inhibitory activity and the strong absorption were found in the same fraction in all separation systems, both features were assumed to belong to the same compound. This compound, which is further characterized below, was named fischerellin. According to the agar diffusion assay, two other less inhibitory substances that have not been studied further were present in the crude extract. The inhibitory compounds were completely extracted with lipophilic solvents, and no inhibitory activity was left in the cell residue when tested with the agar diffusion assay. The yields of inhibitory activity of the medium were 50-100-fold lower than the yields of the cells that were suspended in the medium.

Characterization of fischerellin. Fischerellin was readily soluble in several organic solvents, including methanol, ethanol, acetonitrile, acetone, diethylether and tert-butylmethylether, but was only weakly soluble in water. Freeze dried cells, methanolic extracts, and the purified compound could be stored for months at $+4^{\circ} \mathrm{C}$ without any loss of activity. Fischerellin proved to be very heat resistant: unchanged activities and peak heights (absorption at $267 \mathrm{~nm}$ ) after treatment for $1 \mathrm{~h}$ at $100^{\circ} \mathrm{C}$ were obtained with the HPLC separation. No differences in the yield of fischerellin were found after extraction with $50 \%$ methanol at $\mathrm{pH} 1, \mathrm{pH} \mathrm{7}$, and $\mathrm{pH} 13$ at room temperature. Treatment with $1 \mathrm{M}$ hydrochloric acid at $80^{\circ} \mathrm{C}$ for $1 \mathrm{~h}$ showed no effect, while $1 \mathrm{M}$ sodium hydroxide at $80^{\circ} \mathrm{C}$ for $1 \mathrm{~h}$ led to the decomposition of fischerellin and loss of its inhibitory activity. Fischerellin could not be retained efficiently on either anionic or cationic exchange resins. Therefore, the presence of carboxy-and aminogroups in the molecule can be ruled out.

When HPLC-purified fischerellin was subjected to capillary gas chromatography/mass spectrometry 


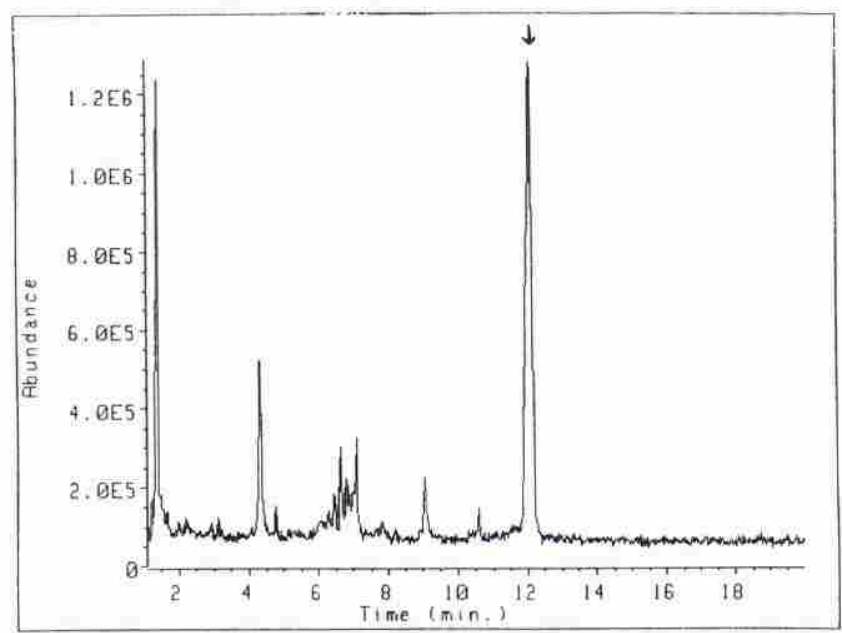

FIG. 2. GC separation of purified fischerellin (arrow).

a strong peak was obtained that exhibited a molecular ion of $\mathrm{m} / z 408$ at a retention time of $12.2 \mathrm{~min}$ (Fig. 2). The molecular ion shifted to $m / z 418$ when the substance was hydrogenated over platinum under hydrogen gas. Fischerellin showed a distinct ultraviolet absorption spectrum with maxima at 213 , 240, 252, 267, 283, and $301 \mathrm{~nm}$. Hydrogenated fischerellin lost the maxima at 252, 267, and 283 nm (Fig. 3). H-reactive substituents did not occur in the molecule as neither the treatment of fischerellin with acetic anhydride $\left(30 \mathrm{~min}, 70^{\circ} \mathrm{C}\right)$ nor BSTFA in DMFA changed the retention time or absorption intensity upon separation by HPLC nor the retention time or mass fragmentation pattern after GC/ MS.

Distribution of fischerellin in the genus Fischerella. To determine whether or not the production of fischerellin is restricted to $F$, muscicola, two other species of Fischerella were investigated. By HPLC separation and UV spectroscopy, fischerellin could be clearly identified in $F$. ambigua. Extracts of the nonaxenic $F$. tisserantii exhibited slight absorptions at 267 and $283 \mathrm{~nm}$ at the fischerellin retention time in HPLC, and the corresponding fraction was inhibitory in the agar diffusion assay. Fischerellin may, therefore, be present also in this species.

Inhibitory activity. Fischerellin purified by HPLC inhibited the growth of green algae as well as several previously untested cyanobacteria on agar (Table 1). Inhibition of cyanobacteria was about 50-1000-fold stronger than the inhibition of the chlorophyte genera Ankistrodesmus, Nannochloris, and Scenedesmus. However, fischerellin did not inhibit the growth of aquatic and soil eubacteria (Table 1).

The inhibitory effect of fischerellin could also be observed in liquid cultures of Synechococcus PCC 6911 when the inhibitor was added dissolved in ethanol (Fig. 4). Immediately upon addition to exponentially growing cultures of Synechococcus, fischerellin inhib- a)

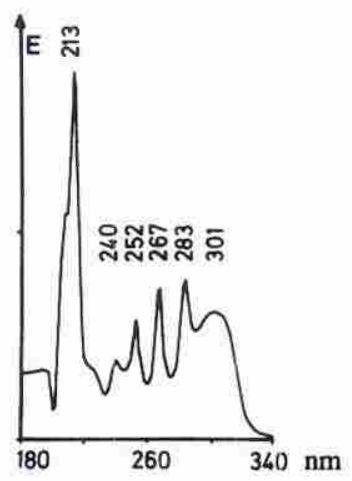

b)

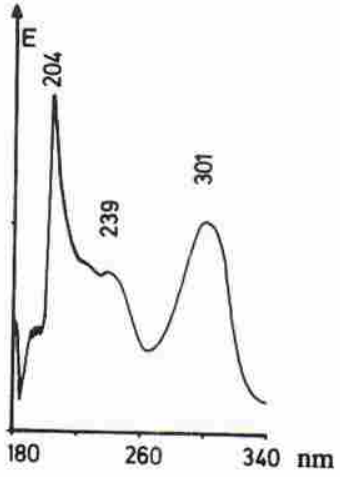

Fig. 3. UV-spectra in methanol: a) fischerellin, b) hydrogenated fischerellin.

ited the increase of optical density at $530 \mathrm{~nm}$, cell number, chlorophyll $a$, and protein concentration. When $150 \mu \mathrm{L}$ of a relatively dilute solution of fischerellin $\left(A_{267}=0.1\right)$ were added, the growth of Synechococcus was significantly and immediately inhibited, but the cells recovered after one week. With more highly concentrated solutions of fischerellin $\left(A_{267}=0.5\right)$, no recovery of the cells was observed. Assuming a molar absorption coefficient of 6000 (assumed for an extended aromatic or conjugated system), the effective concentration of fischerellin appears to be in the range of a few $\mathrm{ng} \cdot \mathrm{mL}^{-1}$. According to this assumption Fischerella contains 100 $150 \mu \mathrm{g}$ of fischerellin per gram dry weight. This is less than has been found for cyanobacterin in $\mathrm{Scy}$ tonema hofmanni and hapalindole A in Hapalosiphon fontinalis. The compounds were reported to be present in the cells at a concentration of 3 and $5.8 \mathrm{mg}$. $\mathrm{g}^{-1}$ dry weight, respectively (Pignatello et al. 1983, Moore et al. 1984).

Mode of action of fischerellin. Because fischerellin appeared to inhibit specifically the growth of photosynthetic organisms in the light (Table 1) and no effect on respiratory electron transport could be found with Nannochloris (data not shown), experiments were conducted with the P9 strain of Anabaena (Table 2) to determine whether photosynthesis was affected. When PS II was inhibited by DCMU, the electron flow between the artificial electron donor (DCPIP reducted by sodium ascorbate) and acceptor (PNDA) of PS I showed no difference when either ethanol alone or with fischerellin were added. However, the electron flow from water to DCPIP, which accepts electrons from PS II (Trebst 1972), was effectively inhibited by fischerellin.

\section{DISCUSSION}

In this paper we describe a new algicidal substance, which we term "fischerellin," from the benthic cyanobacterium Fischerella muscicola. Fischerellin is a low molecular weight, lipophilic, and polyunsaturated compound. Its protease insensitiv- 
TABLE 1. Inhibition of growth of different indicator strains by fischerellin. Growth inhibition of indicator strains was determined by the agar diffusion assay. The amount of fischerellin and the area of lysis were taken into consideration. +++ very strong inhibition, ++ strong inhibition, + weak inhibition, - no inhibition observed.

\begin{tabular}{|c|c|c|}
\hline Indicator strain & Source & Inhibition \\
\hline \multicolumn{3}{|l|}{ Cyanobacteria } \\
\hline $\begin{array}{l}\text { Anabaena variabilis P9 } \\
\text { derivative of ATCC } 29413 \\
\text { Anabaena sp. ATCC } 27893\end{array}$ & R. D. Simon & +++ \\
\hline $\begin{array}{l}\text { PCC } 7120 \\
\text { Phormidium sp. UTEX } 1540 \\
\text { Synechococcus sp. PCC } 6911 \\
\text { Synechogystis spec. CB-3 }\end{array}$ & $\begin{array}{l}\text { R. Haselkorn } \\
\text { UTEX } \\
\text { PCC } \\
\text { T. Vaara }\end{array}$ & $\begin{array}{l}+++ \\
++ \\
+++ \\
+++\end{array}$ \\
\hline \multicolumn{3}{|l|}{ Chlorophyceae } \\
\hline $\begin{array}{l}\text { Ankistrodesmus falcatus } \\
\text { SAG 202-3 }\end{array}$ & SAG & ++ \\
\hline $\begin{array}{l}\text { Nannochloris spec, SAG 55-81 } \\
\text { Scenedesmus armatus }\end{array}$ & SAG & ++ \\
\hline $\begin{array}{l}\text { SAG } 276-4 \mathrm{c} \\
\text { Scenedesmus communis }\end{array}$ & B. Meier & + \\
\hline $\begin{array}{l}\text { SAG 276-46 } \\
\text { Scenedesmus falcatus }\end{array}$ & SAG & + \\
\hline $\begin{array}{l}\text { SAG } 2.81 \\
\text { Scenedesmus obliquus }\end{array}$ & $\begin{array}{l}\text { SAG } \\
\text { B. Hickel }\end{array}$ & $\begin{array}{l}+ \\
++\end{array}$ \\
\hline \multicolumn{3}{|l|}{ Eubacteria } \\
\hline $\begin{array}{l}\text { Alcaligenes eutrophus } \\
\text { DSM } 531 \\
\text { Arthrobacter globiformis }\end{array}$ & M. Höfle & - \\
\hline DSM 820124 & M. Höfle & - \\
\hline Bacillus cereus DSM 626 & M. Höfle & - \\
\hline Bacillus subtilis DSM 347 & M. Höfle & - \\
\hline $\begin{array}{l}\text { Cytophaga johnsonae C21 } \\
\text { Pseudomonas fluorescens }\end{array}$ & M. Höfle & - \\
\hline DSM 50090 & M. Höfle & - \\
\hline
\end{tabular}

Sources: R. D. Simon, Dept. of Biology, State University of New York Geneseo, New York; R. Haselkorn, Dept. Molecular Genetics and Cell Biology, University of Chicago, Illinois; PCC, Pasteur Culture Collection, Institut Pasteur, Paris, France; T. Vaara, Helsinki, Finland; UTEX, The Culture Collection of Algae, University of Texas at Austin Collection, Dept. of Botany, Austin, Texas: SAG, Sammlung von Algenkulturen, Pflanzenphysiologisches Institut der Universität, Göttingen, FRG; B. Meier, B. Hickel, and M. Höfle, Max-Planck-Institut für Limnologie, Plön, F.R.G.

ity and ability to diffuse through dialysis membranes (Flores and Wolk 1986) are consistent with the molecular weight of 408 deduced from the mass spectrum. The mass spectrum did not show ions $(M+2)$, which would indicate atoms of chlorine and bromine. Because after hydrogenation the molecular ion shifted from $\mathrm{m} / \mathrm{z} 408$ to $\mathrm{m} / \mathrm{z} 418$, at least five double bonds or an equivalent amount of triple and double bonds can be assumed in the molecule. The loss of maxima at 252,267 , and $283 \mathrm{~nm}$ in the UV spectrum after hydrogenation further indicated the presence of conjugated double bonds.

Several benthic cyanobacteria that belong to the typological group V (Rippka et al. 1979) have recently been shown to produce physiologically active compounds. The morphological similarities of these organisms may also be accompanied by similarities in their secondary metabolism. Although it remains possible that fischerellin has a structure related to
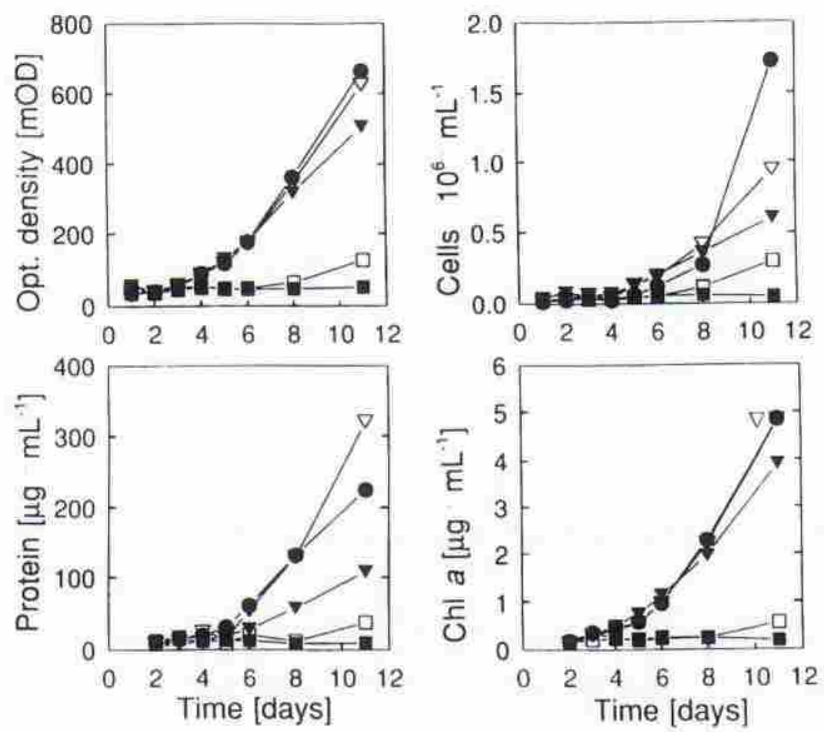

Fig. 4. Effect of fischerellin on growth parameters of Symechococcus PCC 6911: optical density at $530 \mathrm{~nm}$, cell number, chlorophyll $a$, and protein concentration. Fischerellin dissolved in ethanol was added to the cultures during the early exponential growth phase (third day of experiment). The control cultures received no (-) or equal amounts of ethanol $\left(1 \mu \mathrm{L} \cdot \mathrm{mL}^{-1}\right.$ culture medium; $\nabla$ ). The amount of added fischerellin was determined spectrophotometrically; concentrations equivalent to $\mathrm{A}_{267}=0.005$ $(\nabla), \mathrm{A}_{267}=0.1(\square)$, and $\mathrm{A}_{267}=0.5$ (ם) were added.

hapalindole, some features of fischerellin appear inconsistent with hapalindole $\mathrm{A}$ and other compounds from the edaphic cyanobacterium Hapalosiphon fontinalis (Ag.) Bornet, strain V-3-1 (Moore et al. 1984)

TABLE 2. Effect of fischerellin on photosynthesis of Anabaena P9. Basal rate of PS I was determined after addition of DCMU, of PS II after addition of DCPIP, and of PSI + II without any addition. Electron flow rates were determined afier addition of sodium ascorbate, DCPIP, and PNDA in PSI and after addition of fischerellin, atrazine, or ethanol in both PS. The difference is the electron flow rate minus basal rate. The oxygen consumption and evolution by PS I, PS II, and PS I+II were determined by a Clark type electrode. PS $I+I I$ was determined directly, PS I and PS II after decoupling using artificial electron acceptors and donors. Fischerellin was added as $10 \mu \mathrm{L}$ of an ethanolic solution having the indicated value of $A_{26 \%}$. Controls were performed with an equal volume of ethanol or without additions.

\begin{tabular}{lrrr}
\hline \hline & \multicolumn{3}{c}{$\begin{array}{c}\text { Oxygen exchange } \\
\left.\text { Amol } \mathrm{O}_{2} \cdot \mathrm{mg} \mathrm{Ch}^{-1} \cdot \mathrm{h}^{-1}\right)\end{array}$} \\
\cline { 2 - 4 } \multicolumn{1}{c}{ Addition } & Basal rate & $\begin{array}{c}\text { Electron } \\
\text { flow rate }\end{array}$ & Difference \\
\hline PS I + II & & & \\
Ethanol & 81 & 81 & 0 \\
Fischerellin $\mathrm{A}_{267}=0.1$ & 68 & 42 & -26 \\
Fischerellin $\mathrm{A}_{267}=10.0$ & 47 & 0 & -47 \\
PS I & & & \\
Control & 8 & -205 & -213 \\
Ethanol & 9 & -173 & -182 \\
Fischerellin $\mathrm{A}_{267}=1.0$ & 8 & -173 & -181 \\
PS II & & & \\
Ethanol & 38 & 30 & -8 \\
Fischerellin $\mathrm{A}_{267}=0.1$ & 40 & 21 & -19 \\
Fischerellin $\mathrm{A}_{267}=0.25$ & 34 & 0 & -34 \\
Atrazine $(17 \mu \mathrm{M})$ & 50 & 5 & -45 \\
\hline
\end{tabular}


and the hapalindolinones from Fischerella ATCC 53558 (Schwartz et al. 1987). The mass spectrum gave no indication of the presence of chlorine atoms, and the stability of the molecule to acidic hydrolysis is inconsistent with the presence of an isonitrile (Bornemann et al. 1988) or isothiocyanate group, both being characteristic of the hapalindoles (Moore et al. 1984). The molecular weights of the hapalindoles are also much lower than that of fischerellin.

In addition to $F$. muscicola, $F$. ambigua and $F$. tisserantii showed inhibitory activity. Our investigations indicate that fischerellin may be present in extracts of the nonaxenic $F$. tisserantii, but the HPLC separations were not as good as with extracts of the axenic strains. However, fischerellin could be clearly identified in $F$. ambigua. The production of fischerellin may, therefore, be a characteristic feature of the genus Fischerella.

Because fischerellin strongly inhibits photosynthetic organisms, chlorophytes as well as cyanobacteria, it is an algicide. Cyanobacterin, an algicide from Scytonema hofmanni, also inhibits PS II (Mason et al. 1982, Gleason and Paulson 1984), but unlike fischerellin contains an atom of chlorine and has a higher molecular weight (Pignatello et al. 1983). Other biogenic algicides that inhibit photosynthesis have been isolated from Pandorina morum (Patterson et al. 1979) and Chara (Wium-Andersen et al. 1982). The first was of unknown structure and inhibited the electron flow of PS II, the latter were cyclic sulfur compounds and active against epiphytic Nitzschia palea and natural phytoplankton. Hapalindole $\mathrm{A}$ of $\mathrm{H}$. fontinalis also exhibits antialgal activity (Moore et al. 1984). With the exception of the active extract of Pandorina, all of these inhibitory substances are lipophilic. The ease with which lipophilic compounds can pass through cell membranes and can be accumulated in the thylakoid membranes of the target organisms may be responsible for this feature. In the two-dimensional habitat of algal and cyanobacterial mats, direct contact between photosynthetic organisms is quite common, and an exchange of allelochemicals between cells that are attached or close to each other can easily be assumed. In these habitats allelochemical interactions seem to be a powerful competitive strategy. Studies of the ecological impact of fischerellin as an allelochemical are warranted.

This work was supported by Volkswagen Stiftung (1/63 733) and the U.S. Department of Energy under contract DE-ACO2-76E.RO1338. We gratefully acknowledge helpful discussions with $\mathrm{E}$. von Elert, MPI für Limnologie, during the isolation of fischerellin.

Allen, J. F. \& Holmes, N. G. 1986. Electron transport and redox titration. In Hipkins, M. F. \& Baker, N. R. [Eds.] Photosynthesis Energy Transduction. IRL Press, Oxford, pp. 103-41.

Bornemann, V., Patterson, G. M. L. \& Moore, R. E. 1988. Isonitrile biosynthesis in the cyanophyte Hapalosiphon fontinalis. J. Am. Chem. Soc. 110:2339-40.

Cohen, Y. \& Rosenberg, E. 1989. Microbial Mats-Physiological
Ecology of Benthic Mucrobial Communities. American Society for Microbiology, Washington D.C., 494 pp.

Collins, V. G. 1963. The distribution and ecology of bacteria in freshwater. Proc. Soc. Wat. Treat. Exam. 12:40-56.

Flores, E. \& Wolk, C. P. 1986. Production, by filamentous, nitrogen-fixing cyanobacteria, of a bacteriocin and of other antibiotics that kill related strains. Arch. Microbiol. 145:215-9.

Gleason, F. K. 1990. The natural herbicide, cyanobacterin, specifically disrupts thylakoid membrane-structure in Euglena gracilis strain Z. FEMS Microbiol. Lett. 68:77-81.

Gleason, F. K. \& Baxa, C. A. 1986. Activity of the natural algicide, cyanobacterin, on eucaryotic microorganisms. FEMS Microbiol. Lett. 33:85-8.

Gleason, F. K. \& Case, D. E. 1986. Activity of the natural algicide, cyanobacterin, on angiosperms. Plant Physiol. 80:834-8.

Gleason, F. K. \& Paulson, J. L. 1984. Site of action of the natural algicide, cyanobacterin, in the blue-green alga, Synechococcus sp. Arch. Microbiol. 138:273-7.

Jüttner, F. 1982. Mass cultivation of microalgae and phototrophic bacteria under sterile conditions. Proc. Biochem. 17:2-7.

Jüttner, F., Leonhardt, J. \& Möhren, S. 1983. Environmental factors affecting the formation of mesityloxide, dimethylallylic alcohol and other volatile compounds excreted by $A n$ abaena rylindrica. J. Gen. Microbiol. 129:407-12.

Keating, K. I. 1977. Allelopathic influence on blue-green bloom sequence in a eutrophic lake. Science (Wash. D.C.) 196:885-7. 1978. Blue-green algal inhibition of diatom growth: transition from mesotrophic to eutrophic community structure. Science (Wash. D.C.) 199:971-3.

Kuhl, A. 1962. Zur Physiologie der Speicherung kondensierter anorganischer Phosphate in Chlorella. In Deutsche Botanische Gesellschaft [Ed.] Beiträge zur Physiologie und Morphologie der Algen. Fischer Verlag, Stuttgart, pp. 157-66.

Lefevre, M. 1964. Extracellular products of algae. In Jackson, D. F. [Ed.]Algae and Man. Plenum Press, New York, pp. 33767.

Mason, C. P., Edwards, K. R., Pignatello, J., Carlson, R. E., Gleason, F. K. \& Wood, J. M. 1982. Isolation of chlorine-containing antibiotic from the freshwater cyanobacterium Soytonema hofmanni. Science (Wash. D.C.) 215:400-2.

Molisch, H. 1937. Der Einfluss einer Pflanze auf die andere-Allelopathie. Fischer Verlag, Jena, $106 \mathrm{pp}$.

Moore, R. E., Cheuk C. \& Patterson, G. M. L. 1984. Hapalindoles: new alkaloids from the blue-green alga Hapalosiphon fontinalis. J. Am. Chem. Soc. 106:6456-7.

Moore, R. E., Cheuk, C., Yang, X. G., Patterson, G. M. L., Bonjouklian, R., Smitka, T. A., Mynderse, J. S., Foster, R. S., Jones, N. D., Swartzendruber, J. K. \& Deeter, J. B. 1987a. Hapalindoles, antibacterial and antimycotic alkaloids from the cyanophyte Hapalosiphon fontinalis. J. Org. Chem. 52:103643.

Moore, R. E., Yang, X. G. \& Patterson, G. M. L. 1987b. Fontonamide and anhydrohapaloxindole $\mathrm{A}$, two new alkaloids from the blue-green alga Hapalosiphon fontinalis. J. Org. Chem. 52:3773-6.

Moore, R. E., Yang, X. G., Patterson, G. M. L., Bonjouklian, R. \& Smitka, T. A. 1989. Hapalonamides and other oxidized hapalindoles from Hapalosiphon fontinalis. Phytochemistry 28: 1565-7.

Paerl, H. W. 1988. Growth and reproductive strategies of freshwater blue-green algae (cyanobacteria). In Sandgren, C. D. [Ed.] Growth and Reproductive Strategies of Freshwater Phytoplankton. Cambridge University Press, Cambridge, pp. 261315.

Patterson, G. M. L., Harris, D. O. \& Cohen, W. S. 1979. Inhibition of photosynthetic and mitochondrial electron transport by a toxic substance isolated from the alga Pandorina morum. Plant Sci. Letl. 15:293-300.

Pignatello, J. J., Porwoll, J., Carlson, R. E., Xavier, A., Gleason, F. K. \& Wood, J. M. 1983. Structure of the antibiotic cyanobacterin, a chlorine-containing $\gamma$-lactone from the freshwater cyanobacterium Scytonema hofmanni. J. Org. Chem. 48: 4035-8. 
Pratt, R. 1942. Studies on Chlorella iulgaris. V. Some properties of the growth inhibitor formed by Chtorella cells. Am. J. Bot. 31:418-21.

Rice, E. L. 1984. Allelopathy. Academic Press, Orlando, 422 pp. Rippka, R., Deruelles, J., Waterbury, J. B., Herdman, M. \& Stanier, R. Y. 1979. Generic assignments, strain histories and properties of pure cultures of cyanobacteria. J. Gen. Microbiol. 111:1-61.

Schaffner, W. \& Weissmann, C. 1973. A rapid, sensitive and specific method for the determination of protein in dilute solution. Anal. Biochem. 56:502-14.

Scherer, S., Häfele, U., Krüger, H. J. \& Böger, P. 1988. Respiration, cyanide-insensitive oxygen uptake and oxidative phosphorylation in cyanobacteria. Physiol. Plant. 72:379-84.

Schwartz, R. E., Hirsch, C. F., Springer, J. P., Pettibone, D. J. \&
Zink, D. L. 1987. Unusual cyclopropane-containing hapalindoles from a cultured cyanobacterium. J. Org. Chem. 52: $3704-6$.

Trebst, A. 1972. Measurement of Hill reactions and photoreduction. In Colowick, S. P. \& Kaplan, N. O. [E.ds.] Methods in Enzymology, Vol. 24. In San Pietro, A. [Ed.] Photosynthesis and Nitrogen Fixation. Academic Press, New York, pp. 146-65.

Wium-Andersen, S., Anthoni, U., Christophersen, C. \& Houen, G. 1982. Allelopathic effects on phytoplankton by substances isolated from aquatic macrophytes (Charales). Oikos 39:187-90.

Wu, J. T. \& Jüttner, F. 1988. Differential partitioning of geosmin and 2-methylisoborneol between cellular constituents in $\mathrm{Os}_{\text {s- }}$ cillatoria tenuis. Arch. Microbiol. 150:580-3. 